\title{
Interleukin-12 Receptor Subunit Beta-1
}

National Cancer Institute

\section{Source}

National Cancer Institute. Interleukin-12 Receptor Subunit Beta-1. NCI Thesaurus. Code C38917.

Interleukin-12 receptor subunit beta-1 (662 aa, $73 \mathrm{kDa}$ ) is encoded by the human

IL12RB1 gene. This protein plays a role in interleukin-12 binding and signal transduction. 